\title{
Capacity building modules for public libraries to support small-scale business enterprises in Meru County, Kenya
}

\author{
Paul Maku Gichohi ${ }^{1}$, Omwoyo Bosire Onyancha ${ }^{2}$ and Frankwell W. Dulle ${ }^{3}$ \\ pmakuster@gmail.com ORCID: orcid.org/0000-0003-1593-4642 \\ onyanob@unisa.ac.za ORCID: orcid.org/0000-0002-6699-6782 \\ fwdulle@suanet.ac.tz ORCID: orcid.org/0000-0003-2016-6596
}

\author{
Received: 21 June 2017 \\ Accepted: 1 August 2017
}

\begin{abstract}
The lack of well-structured capacity building programmes is a serious drawback to the effective development of small-scale business enterprises (SBEs) in Kenya. Public libraries as community information centres can collaborate with other stakeholders in facilitating the required skills. This study investigated the training needs of SBE traders and public library staff with the aim of proposing capacity building modules that can be considered by public libraries in Meru County, Kenya in their endeavour to support the SBEs. In implementing the study, a mixed methods approach was used and the survey research design adopted. Cluster and systematic sampling techniques were used in getting 355 SBE traders while census was used on twenty-one library staff and on two staff from Meru County government. Interviews and questionnaires were used to collect the required data. The response rate was $83.4 \%$ and $95 \%$ for SBE traders and public library staff respectively. Descriptive statistics and thematic techniques were used to analyse the data. We used the findings of this study and the scholarly insights from previous studies to propose two sets of capacity building modules: for SBE traders and for the public library staff. The training areas comprise business information literacy, technology competency, and nature of information in the business domain. We recommend the adoption of the proposed modules in public libraries in Kenya in elevating support and value contribution in the development of the small business community. We further recommend a training policy for SBEs and the recruitment of experienced, skilled and knowledgeable business librarians.
\end{abstract}

Keywords: Capacity building programmes, business training programmes, public libraries, SBE training, user education programme

\section{Introduction and conceptual setting}

Successes in small-scale business enterprises (SBEs) require proper business information, education and training for business owners, firms' employees and for other people involved in the support system. Bowen, Morara and Mureithi (2009) observed a positive relationship between business success and entrepreneurial training of business owners. Many smallscale business traders, however, lack entrepreneurial skills (Parvin 2012: 253), usually acquired through education and training. The need for education and training for SBEs presents a good opportunity for public libraries to advance their contribution to community development by going beyond mere stocking and providing access to business information. One way a public library can contribute value to the development of SBEs is through capacity building programmes. These programmes can be offered in collaboration with key stakeholders in the business domain if there is a lack of expertise among library staff. In this context, we define 'capacity building' as the continuous interventions that are aimed at empowering an individual or groups of individuals with the requisite understanding, skills and knowledge that help to unleash and enhance abilities to overcome underlying hindrances to the achievement of the desired results. In this study, the capacity building module constituted well-structured training content that lead to the improvement of individual competence that is necessary for running and supporting SBEs and their employees in pursuing and sustaining business endeavours. The training module also includes the people who are involved in providing support to the SBEs. The support systems in this context are perceived to come from the various sources, one of which is public libraries due to their role as community information centres.

Previous studies such as those of Kinnell, Feather and Matthews (1994), Spencer, Ruston and Duncan (2004) and Marfleet (2006) have shown how public libraries are going the extra mile in delivering value to the community. These studies particularly revealed some capacity building initiatives that had been undertaken by public libraries in collaboration with other stakeholders which included: providing professional advice on how to access and retrieve information; holding business training workshops either singly or through collaborations and partnerships; offering a consultation service to the

1. Paul Maku Gichohi holds a PhD in Library and Information Science from the University of South Africa and is acting Deputy University Librarian, Kenya Methodist University

2. Omwoyo Bosire Onyancha is Research Professor in the Department of Information Science, University of South Africa

3. Frankwell Dulle is Professor at the Sokoine University of Agriculture (SUA), Tanzania 
business community; and providing normative guidance to small enterprises in various areas such as market research, trademarks and designs among others. Another key capacity building initiative noted for the public library was the provision of skills in job searching (Online Computer Library Centre [OCLC] 2011: 2). During the economic downturn in 2008, most public libraries in the United States of America (USA), for example, were reported by Wilson (2013: 4) to have started offering information services to job seekers on available jobs and careers, as well advice on how to write application letters and a curriculum vitae. Furthermore, a survey by the American Library Association (Rosa 2015: 10) found that nearly all $(97.5 \%)$ public libraries in the USA were offering free wireless internet access, which presented library staff as technology supporters. Further capacity development initiatives are related to public library staff. The study by Sebina (2009: 65) stressed the role of a public library's staff in repackaging and disseminating business information to small enterprises, actions that stopped them from losing relevance. Underwood (2009), when advocating for business corners, recommended community training forums at public libraries, which should be delivered by librarians using local languages in order to empower people with business skills. Other research, such as that of dos Santos (2009), Wilson (2013), Spencer, Ruston and Duncan (2004), the OCLC (2011) and Hosono (2006), have also supported the need for business training programmes at public libraries. These authors further identified the training areas of such programmes, which included: legal matters affecting businesses; human resources management; the use of social media to leverage business growth and building a business brand; and understanding tax and filing of returns.

The foregoing discussion attests to the need for business information professionals to be duly prepared and informed in order to be resourceful in supporting the SBEs. This further reveals a need for the training of concerned officers who will henceforth be referred to as the business librarians. A business librarian is an information professional who offers specialised information services to the business community in response to their information needs (Sulouff et al. 2005, O'Connor \& Marien 2002). Studies by Wilson and Train (2006), Kassim (2010) and Underwood (2009) emphasised the need for business librarians to be proficient and fully familiar with the business domain, and to be in possession of the requisite information searching skills (Patterson \& Martzoukou 2012) in order to be actively involved in assisting modern business information seekers. Smeaton and Davis (2014) opined that, without subject knowledge in business, business librarians may not be able to maintain the quality of business information services. This, according to Trenner (2013: 31), helps to reposition a business librarian as a coach, adviser, consultant, mentor and a counsellor.

\subsection{Small-scale business enterprises and capacity building initiatives}

Small-scale business enterprises are indispensable catalysts and important contributors to economic growth: they facilitate structural reforms, rapid industrialisation and social cohesion, and result in less crime within a society (Cravo 2010: 713 , Karadag 2015: 26, Obasan 2014: 168, Cunningham 2011: 39, Sherifat 2013: 22, Lin 1998: 43). They enable the testing and commercialisation of business ideas, and are seen as the driving power in China's socialist market economy (Cunningham 2011: 39), as well as in Taiwan's (Lin 1998: 43). They are known for creating jobs in countries such as Turkey, the USA, England, France, Italy, India, Japan, Korea and many other developing countries (Kozan, Öksoy \& Özsoy 2006: 115). For example, in Nigeria, they accounted for $70 \%$ of national industrial employment in 2010 (Aworemi, Abudul-Azeez \& Opoola 2010: 93). In addition to the above significant effects, SBEs contribute immensely to the reduction of poverty in Kenya (Kenya National Bureau of Statistics 2014: 87).

The above contributions signal the crucial need for systems that support the development of SBEs across all countries. However, several previous studies, such as those by Wynne and Lyne (2003) and Philip (2011), indicated that many SBEs suffer due to a lack of financial and non-financial support. Individual competence is one of the key non-financial support systems needed by SBEs, which can be realised particularly through education, training and accrued experience. Notably, the major stages that a business undergoes as it develops comprises idea generation, opportunity analysis, planning, implementation and management of business growth. To be successful, one requires a high level of individual competence without which one would find it very difficult to start and run a successful business. This study concerns the lack of individual competence as a serious drawback in the running and supporting of SBEs, and hence the need for interventions that can address the situation.

Education and training in building individual competence in business cannot be overemphasised. Reviewed entrepreneurship theories and published studies have stressed the need to enhance individual competence in business. For example, the economic theory of entrepreneurship argues that people can be trained to acquire the requisite competence when pursuing a given economic activity. Notably, competence magnifies one's knowhow, for example, when configuring the marketing mix, crafting growth strategies, building distinctive competitive competencies, and in ensuring communication flow and good customer relationships in business (Anga 2014: 142, Coy et al. 2007: 183). It also facilitates the understanding, utilisation and dissemination of business information. Philip (2011: 118) noted that when SBE traders lack education and training in business matters, they face difficulties in assembling and interpreting business information. The lack of requisite skills among SBE traders to retrieve and utilise business information may curtail their ability to initiate and run successful ventures. Similarly, the lack of requisite skills among the people who provide support to SBEs, such as public library staff, may inhibit their ability to provide effective business information support services.

\section{The Meru County: a brief description}

Meru County is one of the forty-seven counties which were created in Kenya after devolution and promulgation of the new constitution in 2010. It is found in the upper eastern region of Kenya and has high agricultural potential as evidenced by fertile soil, fairly good rainfall, and, consequently, many small-scale agribusiness ventures. As reported by Gichohi, Onyancha and Dulle (2016), registered SBEs numbered 4,514 by August 2015 . The majority of these SBEs are widely 
dispersed and solely owned; only a few are jointly owned. The household income for the majority of residents of the area comes from the agricultural sector where most business activities are based on agricultural products and general merchandises such as miraa (khat), bananas, wheat, green vegetables, potatoes, cereals, coffee, tea, French beans, dairy products such as milk, and other consumables (Gichohi, Onyancha and Dulle 2016). Gichohi, Onyancha and Dulle (2016) further noted that the county had only three public libraries as at August 2015, namely, Meru District Library, Mikumbune Community Library and Timau Community Library, which support the mission of the Kenya National Library Service (KNLS) of enhancing socio-economic development. However, their support for the development of SBEs is curtailed by a myriad of challenges in adding value to business information services.

\section{Statement of the problem}

The lack of well-structured capacity building programmes is a serious drawback to the effective development and support of small business enterprises in Kenya. Available studies such as those of Hosono (2006), Wilson (2013) and dos Santos (2009) mainly outlined the delivery modes for capacity building programmes that are commonly found in developed countries. The modes include holding workshops, conferences, seminars, and breakfast meetings among others. These training models can be emulated and adopted in developing countries like Kenya. However, there is not a satisfactory training module that specifically shows the detail and scope of what is taught during the training. Furthermore, the training forums mentioned by these studies are biased toward the small business trader, thereby negating the employees of the firm and the public library staff who are crucial in implementing the training programmes and in supporting the small business traders who visit public libraries for business information. This study sought to address these gaps by exploring the capacity building modules for SBEs and public library staff in fostering the sustainable development of SBEs in Meru County, Kenya. It specifically sought to suggest relevant content that should be covered during the capacity building programme for SBEs and public library staff.

\section{Purpose of the study and research questions}

This study set out to investigate the training needs of SBE traders and public library staff with the aim of proposing the content that should be included in capacity building modules for public libraries in Meru County, Kenya in their endeavour to support the development of small enterprises. The study therefore did not cover other aspects of developing modules, such as the level of teaching, outcomes, certification, and others. It was guided by four research questions:

- $\quad$ Are small-scale business traders trained in business matters?

- What are the business training needs of small-scale business traders?

- What are the business training needs of a public library's staff?

- What should constitute a typical training module for small business traders and public library staff?

\section{Methodology}

This study reports part of the findings from a broad doctoral study on the role of public libraries in the development of SBEs in Meru County, Kenya. A mixed methods approach was used, while the survey research design was adopted in implementing the study. The population of the targeted SBEs was widely dispersed, hence the cluster and systematic sampling techniques were used to sample 355 SBE traders while a census was used on twenty-one library staff and two staff from the Enterprise Development Department (EDD) of Meru County. Interview guides and structured questionnaires were used to collect the required data. Most questions in the questionnaire were closed and utilised a three-to-five-point Likert rating scale. Using the split-half method, the reliability test of the research instrument showed a high Cronbach's alpha score of $87.7 \%$ and $85.3 \%$ for even and odd numbers respectively. Content, construct and external validity of research instruments were ascertained appropriately. The response rate was $83.4 \%$ and $95 \%$ for SBE traders and public library staff respectively. Quantitative data was analysed using IBM's Statistical Product and Service Solutions (SPSS) and Excel while thematic analysis was used on qualitative data acquired from interviews and open-ended questions.

\section{Results}

Results of the interviews and questionnaires are shared below.

\subsection{Training of SBE traders on business matters}

SBE respondents were asked whether they had any training in business matters. The result indicated that, although capacity building is critical for successful business development, the majority of SBE traders, that is, $195(65.9 \%)$, had not been trained in business matters. Only $101(34.1 \%)$ had training in business matters, highlighting a high level of business illiteracy among SBEs. The SBE traders who had some training in business matters were asked to list the details of the training areas that were covered during such training programmes. Answers were important in revealing the scope and relevance of the training. Out of 101 trained SBE traders, only thirty-six responded to this open-ended question. Their responses were thematically summarised as presented in Table 1 .

The results show that training to manage a small business was reported by $25 \%$ of the SBE traders who had received training on business matters. Fewer respondents, that is, $2.8 \%$ of the traders, had training on team building in business, supply-chain management, farm management in agribusiness, marketing in business, and how to take out loans from lending institutions. Most of these training areas appeared relevant, but not exhaustive. Information gathered from the EDD 
in Meru County indicated that the department had not developed an outright training programme and curriculum for the business community. Training on business matters may have had an effect on the way SBE traders were carrying out their businesses and the development thereof.

Table 1 Areas in which SBEs had received training in business matters $(\mathrm{N}=36)$

\begin{tabular}{lcc}
\hline Areas in which SBEs had received training & Number of respondents & Percentage \\
\hline Managing small business effectively & 9 & $25 \%$ \\
Customer care in a business organisation & 8 & $22.2 \%$ \\
How to manage cash flow in business & 3 & $8.3 \%$ \\
First aid in a business organisation & 3 & $8.3 \%$ \\
Financial accounting & 3 & $8.3 \%$ \\
Business opportunities & 2 & $5.6 \%$ \\
Crop and animal husbandry & 2 & $5.6 \%$ \\
Team building in business & 1 & $2.8 \%$ \\
Supply-chain management & 1 & $2.8 \%$ \\
Farm management in agribusiness & 1 & $2.8 \%$ \\
Marketing in business & 1 & $2.8 \%$ \\
How to take out loans from lending institutions & 1 & $2.8 \%$ \\
Security measures in a business organisation & 1 & $2.8 \%$ \\
\hline
\end{tabular}

In order to inform the content for the proposed training module and the support needed for capacity building, SBE traders were further asked to indicate in a three-point Likert rating scale the level of significance of the various suggested business training topics. As shown in Table 2, the overwhelming majority of traders $(205 ; 69.3 \%)$ chose the 'significant' option related to the training topics that were suggested to them. Only twenty-seven $(9.1 \%)$ regarded the suggested business training topics as not significant.

Table 2 Significance of the suggested training topics for SBEs $(\mathrm{N}=296)$

\begin{tabular}{|c|c|c|c|c|}
\hline \multicolumn{2}{|c|}{ Suggested training topics for SBEs } & \multirow{2}{*}{$\begin{array}{c}\begin{array}{c}\text { Significant } \\
\text { n (\%) }\end{array} \\
242(81.8)\end{array}$} & \multirow{2}{*}{$\begin{array}{c}\begin{array}{c}\text { Moderately } \\
\text { Significant } \\
\text { n (\%) }\end{array} \\
46(15.5)\end{array}$} & \multirow{2}{*}{$\begin{array}{c}\begin{array}{c}\text { Not } \\
\text { significant } \\
\mathbf{n}(\%)\end{array} \\
8(2.7)\end{array}$} \\
\hline 1. & How to cope with competition & & & \\
\hline 2. & How to manage savings in a small-scale business & $235(79.4)$ & $46(15.5)$ & $15(5.1)$ \\
\hline 3. & How to manage financial risks and creditors in a small-scale business & $234(79.1)$ & $54(18.2)$ & $8(2.7)$ \\
\hline 4. & Strategies of attracting and maintaining customers & $232(78.4)$ & $33(11.1)$ & $31(10.5)$ \\
\hline 5. & Information on viable source of financing to start and run a small-scale business & $228(77)$ & $37(12.5)$ & $31(10.5)$ \\
\hline 6. & How to handle debt in a small-scale business & $228(77)$ & $53(17.9)$ & $15(5.1)$ \\
\hline 7. & How to evaluate performance of a small-scale business & $226(76.4)$ & $58(19.6)$ & $12(4.1)$ \\
\hline 8. & How to come up with a long-term plan for a small-scale business & $219(74)$ & $62(20.9)$ & $15(5.1)$ \\
\hline 9. & How to stock a small-scale business & $216(73)$ & $45(15.2)$ & $35(11.8)$ \\
\hline 10. & How to market small-scale business products and services & $210(70.8)$ & $79(26.7)$ & $7(2.4)$ \\
\hline 11. & Cash flow management in a small-scale business & $208(70.3)$ & $73(24.7)$ & $15(5.1)$ \\
\hline 12. & Seller-supplier relationship management & $208(70.3)$ & $72(24.3)$ & $16(5.4)$ \\
\hline 13. & Managing the growth of a small-scale business & $203(68.6)$ & $66(22.3)$ & $27(9.1)$ \\
\hline 14. & Ways of starting/establishing a small-scale business & $197(66.6)$ & $62(20.9)$ & $37(12.5)$ \\
\hline 15. & Effective handling of business expenditures and overheads & $197(66.6)$ & $76(25.7)$ & $23(7.8)$ \\
\hline 16. & How to develop a business plan & $195(65.9)$ & $62(20.9)$ & $39(13.2)$ \\
\hline 17. & Managing quality issues in small-scale business enterprises & $191(64.5)$ & $78(26.4)$ & $27(9.1)$ \\
\hline 18. & Handling employees in a small-scale business & $189(63.9)$ & $60(20.3)$ & $47(15.9)$ \\
\hline 19. & Preparing, mitigating and handling disasters affecting small-scale business enterprises & $165(55.7)$ & $88(29.7)$ & $43(14.5)$ \\
\hline 20. & Succession planning for a small-scale business & $165(55.7)$ & $88(29.7)$ & $43(14.5)$ \\
\hline 21. & Insurance information for small-scale business enterprises & $162(54.7)$ & $87(29.4)$ & $47(15.9)$ \\
\hline \multirow[t]{2}{*}{22.} & How to solicit for networks, collaborations and partnerships for a small-scale business & $160(54.1)$ & $85(28.7)$ & $51(17.2)$ \\
\hline & Mean & $205(69.3)$ & $64(21.6)$ & $27(9.1)$ \\
\hline
\end{tabular}

Coping with competition topped the list of significant training needs for the majority of traders $(242 ; 81.8 \%)$, followed by training on financial management $(235 ; 79.4 \%)$, on financial literacy skills $(234 ; 79.1 \%)$, and on matters related to customers $(232 ; 78.4 \%)$, in that order. The suggested training areas that were not very popular with SBE traders, although popular with more than half, were training in insurance for small-scale business enterprises (162; 54.7\%) and training in how to solicit for networks, collaborations and partnerships for a small business (160; 54.1\%). The results show that the suggested training topics were substantively relevant to the SBEs. The high rating on the suggested training topics signalled a high curiosity and need for SBE training on business matters. The results point to the areas in need of capacity building. 
Data collected from the three public libraries reported that none of them was providing training on business matters. The senior staff from EDD who were interviewed said that their staff were conducting some training for SBEs, although inadequate staffing was limiting the desired effectiveness. These findings were critical in developing content for a training module for SBEs. They also informed the scope of the development of the business collection in public libraries.

The authors were also interested in ascertaining the challenges that SBE traders were facing when seeking and accessing business information. Knowledge of these challenges was critical in determining whether they were largely due to lack of education and training in business matters. SBE respondents were provided with a list of suggested challenges and asked to rate each as a 'major challenge', 'average challenge', 'minor challenge', or 'not a challenge'. As indicated in Table 3, the top five challenges that were encountered by SBE traders when seeking business information included: limited skills in seeking or searching for information on businesses, an option selected by $155(52.4 \%)$ respondents; lack of knowledge on the kind of sources for information on businesses that were available to help in business ventures (152; $51.4 \%$ ); information obtained not able to address specific business problems facing SBEs (150; 50.7\%); lack of knowledge on whether the needed business information existed (138; 46.6\%); and the places/providers of information on businesses being distantly located $(137 ; 46.3 \%)$. Three challenges were not regarded as important to SBE traders when accessing business information. These challenges were: being too busy and occupied for time to read materials that contain information on businesses, an option selected by thirty-eight (12.8\%); a dislike for reading (thirty-seven; $12.5 \%$ ); and the language used in sources for information on businesses being difficulty to understand (twenty-nine; $9.8 \%$ ). The results show that there were substantial challenges facing SBE traders when seeking and accessing business information in Meru County. Eleven out of fifteen challenges were largely due to a lack of education and training in business matters, hence the need for intervention programmes. The challenges outlined in Table 3 were further summarised and aggregated as follows: the lack of business information literacy skills; availability and affordability of business information; language barrier; technology incompetence; time and distance limitation; and uninformed information professionals. These challenges seem to permeate the core functions of a public library.

Table 3 Challenges faced by SBEs when seeking and accessing business information ( $\mathrm{N}=296)$

\begin{tabular}{|c|c|c|c|c|c|}
\hline \multicolumn{2}{|c|}{$\begin{array}{l}\text { Challenges encountered by SBEs when accessing business } \\
\text { information }\end{array}$} & \multirow{2}{*}{$\begin{array}{c}\begin{array}{c}\text { It is a major } \\
\text { challenge } \\
\mathbf{n}(\%)\end{array} \\
155(52.4)\end{array}$} & \multirow{2}{*}{$\begin{array}{c}\begin{array}{c}\text { Is an average } \\
\text { challenge } \\
\text { n (\%) }\end{array} \\
54(18.2)\end{array}$} & \multirow{2}{*}{$\begin{array}{c}\begin{array}{c}\text { It is a minor } \\
\text { challenge } \\
\text { n (\%) }\end{array} \\
53(17.9)\end{array}$} & \multirow{2}{*}{$\begin{array}{c}\text { It is not a } \\
\text { challenge to me } \\
\mathbf{n}(\%)\end{array}$} \\
\hline 1. & $\begin{array}{l}\text { I have limited skills in seeking or searching for information on } \\
\text { businesses }\end{array}$ & & & & \\
\hline 2. & $\begin{array}{l}\text { I do not know what kind of sources for information on businesses } \\
\text { are available to help me in my business venture }\end{array}$ & $152(51.4)$ & $60(20.3)$ & $28(9.5)$ & $56(18.9)$ \\
\hline 3. & $\begin{array}{l}\text { The information obtained does not address my specific business } \\
\text { problems }\end{array}$ & $150(50.7)$ & $50(16.9)$ & $63(21.3)$ & $33(11.1)$ \\
\hline 4. & I am not sure whether the business information I need exists & $138(46.6)$ & $68(23)$ & $51(17.2)$ & $39(13.2)$ \\
\hline 5. & $\begin{array}{l}\text { The places/providers of information on businesses are far away } \\
\text { from where my business is located }\end{array}$ & $137(46.3)$ & $66(22.3)$ & $44(14.9)$ & $49(16.6)$ \\
\hline 6. & $\begin{array}{l}\text { The information on starting and running a business venture is } \\
\text { usually not given out easily }\end{array}$ & $123(41.6)$ & $78(26.4)$ & $66(22.3)$ & $29(9.8)$ \\
\hline 7. & I don't know where to obtain information related to my business & $108(36.5)$ & $73(24.7)$ & $75(25.3)$ & $40(13.5)$ \\
\hline 8. & $\begin{array}{l}\text { It takes too long to obtain information on businesses from the } \\
\text { providers }\end{array}$ & $105(35.5)$ & $82(27.7)$ & $69(23.3)$ & $40(13.5)$ \\
\hline 9. & I have no time to visit places that provide information on businesses & $93(31.4)$ & $71(24)$ & $84(28.4)$ & $48(16.2)$ \\
\hline 10. & $\begin{array}{l}\text { Information on businesses is sometimes sold and I do not have the } \\
\text { money to buy it }\end{array}$ & $83(28)$ & $77(26)$ & $61(20.6)$ & $75(25.3)$ \\
\hline 11. & $\begin{array}{l}\text { The people who provide information on businesses do not appear to } \\
\text { be well informed }\end{array}$ & $64(21.6)$ & $48(16.2)$ & $69(23.3)$ & $115(38.9)$ \\
\hline 12. & $\begin{array}{l}\text { I have a challenge in using the modern information retrieval gadgets } \\
\text { such as smart phones, iPads, tablets, and computers in obtaining } \\
\text { information on businesses }\end{array}$ & $42(14.2)$ & $75(25.3)$ & $61(20.6)$ & $118(39.9)$ \\
\hline 13. & $\begin{array}{l}\text { I am too busy and occupied such that I don't get time to read } \\
\text { materials that contain information on businesses }\end{array}$ & $38(12.8)$ & $90(30.4)$ & $55(18.6)$ & $113(38.2)$ \\
\hline 14. & $\begin{array}{l}\text { I do not like reading hence it is difficult to obtain information on } \\
\text { businesses from written materials }\end{array}$ & $37(12.5)$ & $32(10.8)$ & $72(24.3)$ & $155(52.4)$ \\
\hline 15. & $\begin{array}{l}\text { The language used in sources for information on businesses is } \\
\text { difficult for me to understand }\end{array}$ & $29(9.8)$ & $34(11.5)$ & 47 (15.9) & $186(62.8)$ \\
\hline & Mean & $97(32.8)$ & $64(21.6)$ & $60(20.2)$ & $75(25.5)$ \\
\hline
\end{tabular}

Public libraries are expected to provide access to information and knowledge for community development. They are located close to the populace, and this helps them to overcome time and distance challenges of their users. To validate the functional role of a public library, staff were asked to indicate how they perceived the contribution of a public library to community development. The results were summarised by combining both 'strongly agree' and 'agree' responses in order to obtain the percentage agreement level, while the disagreement level was obtained by combining both 'strongly disagree' and 'disagree' responses, which ultimately gave three nominal columns as presented in Table 4.

The five most important contributions of a public library to community development as perceived by library staff were: developing a reading culture and lifelong learning, an option selected by twenty (100\%) respondents; providing helpful 
information for schools and general learning (twenty; 100\%); keeping the public updated (nineteen; 95\%); providing a conducive place to read and revise for exams (nineteen; 95\%); and providing helpful information on available jobs and other working opportunities (seventeen; 85\%). Staff felt that the library had less value when it came to training people on the use of computers (ten; $50 \%$ ); helping people to make contacts and network with others (eight; $40 \%$ ); providing a place to read e-mails (eight; $40 \%$ ); and providing a place to check e-commerce updates and online orders (five; $25 \%$ ).

Table 4 Staffs' perceived value contribution of a public library to community development $(\mathrm{N}=20)$

\begin{tabular}{|c|c|c|c|}
\hline Value contribution of a public library to community development & $\begin{array}{c}\text { Agreement } \\
\text { score } \\
\text { (Strongly agree } \\
\& \text { agree) } \\
\mathrm{n}(\%)\end{array}$ & $\begin{array}{c}\text { Neutral } \\
\mathrm{n}(\%)\end{array}$ & $\begin{array}{c}\text { Disagreement } \\
\text { score } \\
\text { (Strongly disagree } \\
\text { \& disagree) } \\
\mathrm{n}(\%)\end{array}$ \\
\hline 2. Provide helpful information for schools and general learning & $20(100)$ & 0 & 0 \\
\hline 3. Keep the public updated & $19(95)$ & $1(5)$ & 0 \\
\hline 4. Provide conducive place to read and revise for exams & $19(95)$ & 0 & 0 \\
\hline 7. Provide forum for the public to learn new ideas & $16(80)$ & $1(5)$ & $3(15)$ \\
\hline 8. Provide access to valuable intellectual resources; local content that otherwise would be hard to find & $16(80)$ & $2(10)$ & $2(10)$ \\
\hline 9. Provide an environment for social interaction & $16(80)$ & $4(20)$ & 0 \\
\hline 10. Build capacity (skills) in people through various training programmes & $15(75)$ & $2(10)$ & $3(15)$ \\
\hline 11. Provide helpful information on health and wellness & $15(75)$ & $4(20)$ & $1(5)$ \\
\hline 16. Provide free access to online electronic databases to the public & $15(75)$ & $3(15)$ & $2(10)$ \\
\hline 17. Provide helpful information on agriculture & $14(70)$ & $4(20)$ & $2(10)$ \\
\hline 18. Connect people with professional support & $14(70)$ & $4(20)$ & $2(10)$ \\
\hline 19. Provide a place for social enjoyment, leisure, relaxation and rejuvenation of the mind & $14(70)$ & $4(20)$ & $2(10)$ \\
\hline 20. Provide helpful information on politics & $13(65)$ & $7(35)$ & 0 \\
\hline 21. Provide a safe place to hold meetings & $12(60)$ & $2(10)$ & $6(30)$ \\
\hline 22. Provide access to e-government information and services & $11(55)$ & $2(10)$ & $7(35)$ \\
\hline 23. Train people on how to use computers & $10(50)$ & $1(5)$ & $9(45)$ \\
\hline 24. Help people to make contacts and also network with others & $8(40)$ & $7(35)$ & $5(25)$ \\
\hline 25. A place to read e-mails & $8(40)$ & $1(5)$ & $11(55)$ \\
\hline 26. A place to check e-commerce updates and online orders & $5(25)$ & $5(25)$ & $10(50)$ \\
\hline
\end{tabular}

Interestingly, nine out of twenty-seven contributions of a public library to community development had a highly significant value to the SBE traders and employees of a business organisation. These are: providing helpful information on available jobs and other working opportunities (seventeen; 85\%); building capacity (skills) in people through various training programmes (fifteen; 75\%); providing helpful information on business matters and commerce (fifteen; 75\%); equipping the public with information-searching skills (fifteen; 75\%); providing free access to online electronic databases to the public (fifteen; 75\%); providing helpful information on agriculture (fourteen; 70\%); connecting people with professional support (fourteen; $70 \%$ ); training people on the use of computers (ten; 50\%); and helping people make contacts and network with others (eight; 40\%). The list shows the high expectations that SBE traders have of a public library. This information was crucial in developing the proposed capacity building module for the SBE traders and staff of a public library.

\subsection{Training of a public library's staff on business matters}

Gichohi, Onyancha and Dulle (2016) reported dismal engagement and involvement of public library staff in the provision of business information services to SBEs in Meru County. This deficiency could be attributed to many factors, such as the lack of background training in business matters among library staff. Only two out of twenty public library staff respondents (10\%) said that they had background training in business matters. One staff member had a certificate in business administration where entrepreneurship was taught as a basic unit. The other eighteen staff $(90 \%)$ had no prior training/education in business matters. These percentages highlight the need for background training in business matters for all staff who are involved in providing business information for SBEs at public libraries. Training of public library staff on business matters was regarded as critical for the effective provision of business information for SBEs. These responses were very informative in the development of content for a training module that is proposed by this study. 


\section{Proposed capacity building module for SBEs and the public library to support small enterprises}

This study aimed to propose content for capacity building modules for SBE traders and public library staff with the broad goal of supporting the SBEs. One of the key internal environmental factors highlighted by the economic theory of entrepreneurship in business performance is individual competencies in the form of knowledge and skills, which this study has also established as significant in influencing the development of SBEs. However, the majority of SBE traders - 195 $(65.9 \%)$ - in Meru County had no background training in business matters. The Schumpeterian economic theory of entrepreneurship argues that production resources are scarce, hence the business person (entrepreneur) should be equipped with skills and knowledge to configure factors of production for effectiveness in the production process. According to the economic and sociological theories of entrepreneurship, people can be educated and trained to sharpen their skills in business (Gichohi, Onyancha \& Dulle 2016). The economic theory of entrepreneurship specifically argues that one can be trained on techniques for efficient handling of scarce resources and be equipped with skills and knowledge to predict and create strategic responses to the dynamic external environment of a business.

Published literature such as that of Parvin (2012: 253) and Bowen, Morara and Mureithi (2009) has shown the essence of business training skills in nurturing the development of SBEs. It therefore follows that users' training is an important ingredient in the service mix and should be offered by public libraries without charge or with only minimal charges. The Urban Libraries Council (Majarrez et al. 2007: 14) recommended that public libraries have structured training for SBEs. With reference to the findings of this study, coupled with the scholarly insights from the previous published studies, two sets of content for capacity building modules were proposed: the first one is for SBE traders and the second one is for public library staff. Details of these modules are outlined below.

\subsection{Content for training module for SBE traders}

The findings depicted in Tables 1, 2 and 3 led to the two-fold categorisation of the proposed business training module for SBE traders. The first one addresses the knowledge gap of SBE traders in running and managing business operations, while the second one focuses on equipping SBE traders with the technical skills for searching, analysing and utilising business information.

\subsubsection{Training for SBEs on business matters}

The purpose of this training module is to equip SBE traders with the requisite skills and knowledge to run a successful small-scale business. According to analysed information (presented in Tables 1, 2, 3 and 4), the content of the training curriculum should cover all facets of small business growth, and should include but not be limited to: identifying and screening a business idea; strategies for starting/establishing a small business; financing a small business; protecting business ideas; developing a successful business plan; how to cope with competition; finance literacy; saving and investment strategies; how to manage creditors; and strategies for attracting and maintaining customers. Other important content is: management of debtors; monitoring; controlling and evaluating performance; stocks and logistics management; marketing business products and services; branding and brand equity; nurturing creativity and innovation; cash flow management; seller-supplier relationship management; managing growth; customer relationship management; the intricacies of business overheads; how to manage quality issues; and effective management of employees. On planning aspects, the content needs to cover: planning horizons in the small business sector; preparing, mitigating and managing disasters affecting SBEs; business continuity and succession planning; coping with and handling emergencies; and risk management. On providing tips for business growth and survival, the content should cover: building networks, collaborations, linkages and partnerships for a small business; maintaining high productivity and performance; the essentials of team building; farm management in agribusiness; conducting market surveys; and filing tax returns for a small business.

\subsubsection{Training SBEs on accessing and/or utilising business information sources and services}

This kind of training aims to build technical capacity that would enable SBE traders to be self-reliant in searching, retrieving and utilising business information. The challenges of accessing business information (presented in Table 3) are largely because of limited or lack of skills in accessing and retrieving the needed business information - whether from print or nonprint information sources. Bouthillier (2013: 133) reported the lack of expertise and skills in accessing business information as a substantial challenge for SBEs. The study by Chaudhry and Alansari (2013: 168), too, showed that $58.3 \%$ of the investment professionals in Kuwait have a skills deficiency in searching the online databases and portals. Mamafha, Ngulube and Ndwandwe (2014: 4) noted that SBE traders who were using public libraries faced challenges in information access, one of which was the lack of knowledge of the use of ICT tools to retrieve information. Notably, with current proliferations of technology, a lot of business information is available and accessible via the internet. Hence, the skills deficiency in searching online electronic resources would find SBE traders being disadvantaged, resulting in poor business decision-making, which may ultimately affect the growth of a business venture.

Public libraries can help to bridge the above-mentioned gap by providing online information retrieval skills training to SBEs through various modes. With reference to Tables 3 and 4 , the proposed training module for accessing and/or utilising business information sources and services should entail: how to use computers and tablets in small business management; introduction to the internet; library as a place for business information and knowledge; how to search for books in the library; and introduction to business information sources and services. Other important aspects of the training should include: introduction to information searching techniques and methods; online information searching tools; evaluating business 
information sources; managing and utilising business information; online electronic business sources; legal use of business information; and business information and social media.

\subsubsection{Training and development programme targeting the employees of a business organisation}

Volatility in the economic environment requires the continuous reskilling of the workforce. The Urban Libraries Council (Majarrez et al. 2007) recommended initiatives such as workshops for building capacities in employees. Public libraries in Meru County should also respond by keeping and providing access to job and career information sources and providing services that are relevant to both the workforce development agencies and the employees themselves.

With reference to the study by Urban Libraries Council (Majarrez et al. 2007) and the analysed information presented in Tables 1-4, the content of this training module should include but not be limited to the following areas: employable skills; writing a curriculum vitae; surviving a job interview; negotiating a salary deal with an employer; managing one's first employment; personal finance management; matching and balancing personal and business/organisational goals; interpersonal relationships; and personal career planning and management. Other training aspects include: job engagement in a business organisation; job and social life balance; work productivity and performance excellence; managing a business spinoff; leadership and communication in a business organisation; customer care; the power of teamwork; creativity and innovation; retaining and rewarding high performance; growing up in a business organisation; information literacy for employees; social media; and business employees. The training should expand also to include: ICT strategy and business employees; the blue ocean strategy for a business organisation; overcoming job burnout; workplace safety and emergencies; wellness and welfare issues in a business organisation; creating and managing a personal blog and website; giving back to the community; community service opportunities; handling grief and bereavement in a business organisation; and planning for retirement.

\subsubsection{Training module for public library staff in business matters and in information retrieval skills}

This unique training programme is meant to equip public library staff with the knowledge and technical skills to be effective in assisting SBEs. Undoubtedly, with the recent and wide acceptance of mobile technology and e-commerce, many approaches to the provision of business information are changing and will continue to change. In developed countries, this scenario has resulted in the wide use of ICT facilities in providing faster and efficient access to business information (Chiware \& Dick 2008: 152).

The results show the need for public library staff to have in-depth knowledge of business domain information sources and be fully conversant with the intricacies of starting and running a small business. This understanding underscores the need for background training of public library staff in business matters. Unfortunately, $90 \%$ of public library staff said that they had no prior training or education in business matters, which may explain why $21.6 \%$ of SBE traders felt that the people who provide information on businesses do not appear to be well informed. This observation has far-reaching implications for the skills and knowledge that public library staff should have for effective delivery of business information services. The acquisition and possession of requisite knowledge and skills for retrieving business information among public library staff was also noted by Sebina (2009: 65), dos Santos (2009), Wilson (2013), the OCLC (2011) and Hosono (2006). The authors described these skills as critical in asserting professional value in information service provision. According to the analysed information (presented in Tables 1-4), the training module should cover all the areas described in 7.1.1, 7.1.2 and 7.1.3 above, largely because the staff of a public library, as a trusted community information centre, are expected to be fully knowledgeable in all aspects of information inquiry and discovery. In addition to the training modules described in 7.1.1, 7.1.2 and 7.1.3, library staff should be allowed to attend business events, forums, workshops and conferences for exposure and further learning experience.

\section{Relevance, limitations and implications of the proposed content for capacity building modules}

The proposed content for capacity building modules for SBE traders and public library staff is valuable in ensuring the sustainable support of SBEs. It highlights value-adding initiatives by a public library in supporting small business community development. The modules have listed relevant training topics and showed the content and scope of the training. The proposed content for capacity building programmes, however, lacks a detailed curriculum that shows the number of hours that should be spent on each of the proposed topics, the training methodology, the required equipment for facilitating, training outcomes, and the qualification of the facilitators. These limitations form the basis for further research. The modules are, however, relevant in sustainable business community development and inform the manner in which public libraries can support SBEs.

The proposed training modules have implications for policies for supporting SBEs in a public library. They also have implications for staffing, especially the business librarians. Education and training helps the community to overcome social misplacement (brain drain) and displacement (wrong job), and largely provides guidance on career choice and path. This implies the need for appropriate policies that introduce and encourage entrepreneurship education and business literacy to people at an early age in order to entrench positive attitudes toward job and wealth creation. There is a further implication for all learning institutions such as universities, tertiary colleges, polytechnics, technical institutes and schools (primary and secondary). The training of the small-scale business community on business matters also requires policy guidelines by the EDD of Meru County government in order to ensure relevant training topics are adequately covered and administered to all SBEs, regardless of their physical location. The policy should focus on all facets of the small business sector. 


\section{Conclusions and recommendations}

The findings of this study have revealed a high level of business illiteracy among SBE traders and thus the indispensable need for background training on business matters. The training needs of SBE traders were established and are due to business information illiteracy, technology incompetency, and the need to understand the nature and structures of information in the business domain. An elaborate training module with content also for the employees of a business organisation has been proposed. Public libraries have a role to play in providing solutions to the training needs of SBE traders. Their preparedness in delivering this mandate demands that staff have the requisite business information literacy skills, be technology savvy, and be knowledgeable in the business domain. However, the majority of staff working in public and community libraries had no background training in business matters. In order to be effective in supporting the SBEs, content for a capacity building module for public library staff has been proposed. The modes of implementing the proposed modules range from formal classroom settings to workshops, seminars, conferences and customised small business community training sessions. The authors recommend the adoption of the proposed content for capacity building modules in public libraries in Kenya with a view to elevating their valuable contribution to business community development. Also recommended is the recruitment of business librarians who have experience, skills and knowledge in business matters.

\section{References}

Anga, R.M. 2014. Determinants of small and medium scale enterprises in Nigeria. JORIND. 12(1): 140-148 [Online]. http://www.transcampus.org/JORINDV12Jun2014/Jorind\%20Vol12\%20No1\%20Jun\%20Chapter16.pdf (21 June 2015).

Aworemi, J.R., Abudul-Azeez, I.A. and Opoola, N.A. 2010. Impact of socio-economic factors on the performance of smallscale enterprises in Osun State, Nigeria. International Business Research, 3(2): 92-98. DOI: 10.5539/ibr.v3n2p92.

Bouthillier, F. 2013. Access to information for small business managers: examination of some strategies and values. Proceedings of the Annual Conference of CAIS/Actes du congrès annuel de l'ACSI. [Online]. http://www.caisacsi.ca/ojs/index.php/cais/article/view/14 (11 June 2015).

Bowen, M., Morara, M. and Mureithi, S. 2009. Management of business challenges among small and micro enterprises in Nairobi-Kenya. KCA Journal of Business Management, 2(1): 16-31.

Chaudhry, A.S. and Alansari, H. 2013. Use of electronic and digital information by investment professionals in Kuwait. Library Review, 62(3): 157-176. DOI:10.1108/00242531311329482.

Chiware, E.R.T. and Dick, A.L. 2008. The use of ICTs in Namibia's SME Sector to access business information services. Electronic Library, 26(2): 145-157. DOI:10.1108/02640470810864055.

Chiware, E.R.T. 2008. Information Needs and information seeking patterns of small, medium and micro enterprises in Namibia. Information Development, 24(1): 24-36. DOI: 10.1177/0266666907087694.

Coy, S.P., Shipley, M.F., Omer, K. and Khan, R.N.A. 2007. Factors contributory to success: a study of Pakistan's small business owners. Journal of Developmental Entrepreneurship, 12(2): 181-198.

Cravo, T.A. 2010. SMEs and economic growth in the Brazilian Micro-regions. Regional Science, 89(4): 711-734. DOI:10.1111/j.1435-5957.2010.00301.x.

Cunningham, L.X. 2011. SMEs as Motor of growth: a review of China's SMEs development in thirty years (1978-2008). Human Systems Management, 30(1/2): 39-54. DOI: 10.3233/HSM-2011-0736.

dos Santos, V.F. 2009. Public libraries and their contribution towards economic development: a discussion. Library and Information Science Research Electronic Journal, 19(2): 1-9. [Online]. http://libres.curtin.edu.au/libres19n2/Ferreirados-Santos_Vanda_Ess_Op.pdf (27 July 2014).

Gichohi PM, Onyancha, B. and Dulle FW. 2016. How public libraries in Meru county, Kenya address the information needs of small enterprises. Information Development Journal, 34(4): 1-18. [Online]. DOI:10.1177/0266666916667998.

Gichohi PM. 2016. The role of public libraries in the development of small-scale business enterprises in meru County, Kenya. Doctoral Thesis. University of South Africa. [Online]. http://uir.unisa.ac.za/handle/10500/21588 (25 April 2017).

Hosono, K. 2006. Changes in university and public libraries in Japan. IFLA Journal, 32(2): 119-130. DOI:10.1177/0340035206066409.

Karadag, H. 2015. Financial management challenges in small and medium-sized enterprises: a strategic management approach. EMAJ: Emerging Markets Journal, 5(1): 26-40. DOI:10.5195/emaj.2015.67.

Kassim, M.J. 2010. Information needs of Malaysian Bumiputera would-be entrepreneurs. Malaysian Journal of Library \& Information Science, 15(2): 57-69. [Online]. http://e-journal.um.edu.my/filebank/published_article/2802/no.4.pdf (15 July 2014).

Kenya National Bureau of Statistics. 2014. 2014 Economic Survey Report. [Online]. http://www.knbs.or.ke/index.php?option=com_phocadownload\&view=category\&id=107\&ltemid=1181 (25 June 2014).

Kinnell, M., Feather, J. and Matthews, G. 1994. Business information provision for small and medium-sized enterprises in China: the application of marketing models. Library Management, 15(8): 16-23. DOI:10.1108/01435129410071363.

Kozan, M.K., Öksoy, D. and Özsoy, O. 2006. Growth plans of small businesses in Turkey: individual and environmental influences. Journal of Small Business Management, 44(1): 114-129. DOI:10.1111/j.1540-627X.2006.00157.x.

Lin, C.Y. 1998. Success factors of small and medium-sized enterprises in Taiwan: an analysis of cases. Journal of Small Business Management, 36(4): 43-56. 
Majarrez, C.A., Cigna, J., Bajaj, B. and Milam, D.P. Eds. 2007. Making cities stronger: public libraries' contributions to local economic development. Evanston, IL: Urban Libraries Council.

Mamafha, T.M.M., Ngulube, P. and Ndwandwe, S.C. 2014. Utilization of Information and Communication Technologies in public libraries at Ekurhuleni Metropolitan Municipality in South Africa. Information Development, DOI:10.1177/0266666914550214.

Marfleet, J. 2006. Roadmap for the future: where to next? Future provision of business information services at the British Library. Business Information Review, 23(4): 258-263. DOI:10.1177/0266382106072257.

O'Connor, L. and Marien, S. 2002. Recruiting quality business librarians in a shrinking labor market. The Bottom Line, 15(2): 70-74. DOI:10.1108/08880450210427335.

Obasan, K.A. 2014. The Impact of business environment on the survival of small scale businesses in Nigeria. International Journal of Management and Business Responsibility, 4(3): 165-170.

Online Computer Library Centre (OCLC) 2011. How Canadian public libraries stack up. [Online]. http://www.oclc.org/content/dam/oclc/reports/canadastackup/214109cef_how_libraries_stack_up.pdf (19 June 2014).

Parvin, L. 2012. Determinates of women micro-entrepreneurship development: an empirical investigation in rural Bangladesh. International Journal of Economics and Finance, 4(5): 254-260.

Patterson, L. and Martzoukou, K. 2012. An examination of Canadian information professionals' involvement in the provision of business information synthesis and analysis services. Journal of Librarianship and Information Science, 44(1): 47-64. DOl:10.1177/0961000611426215.

Philip, M. 2011. Factors affecting business success of small \& medium enterprises (SMEs). Amity Global Business Review, 6(1): 118-136.

Rosa, K. Ed. 2015. The state of America's libraries: a report from the American Library Association 2015. Chicago: American Library Association. [Online]. http://www.ala.org/news/sites/ala.org.news/files/content/0415_StateAmLib_0.pdf (6 June 2015).

Sebina, T. 2009. Information centres as thriving and open spaces. In Information Services and Community Development. Proceedings of Botswana Library Association (BLA) 2nd National Conference. 30 July - 1 August 2009. Botswana: Botswana Library Association. [Online]. http://bookbooth.ru/Botswana-Library-Association-BLA-2nd-NationalConference--information-services-and-community-develop/7/ccjbjjc (23 July 2014).

Sherifat, Y.O. 2013. Gender differentials in factors affecting performance of small-scale enterprises in Lagos State Nigeria. Innovative Issues and Approaches in Social Sciences, 6(2): 21-39.

Smeaton, K. and Davis, K. 2014. Social technologies in public libraries: exploring best practice. Library Management, 35(3): 224-238. DOI:10.1108/LM-09-2013-0087.

Spencer, N., Ruston, P. and Duncan, S. 2004. Using business information services at the British Library: a case study in breadth and diversity. Business Information Review, 21(1): 53-61. DOI:10.1177/0266382104043607.

Sulouff, P., Bell, S., Briden, J., Frontz, S. and Marshall, A. 2005. Learning about grey literature by interviewing subject librarians: a study at the University of Rochester. College \& Research Libraries News, 66(7): 510-515. [Online]. www.greynet.org/images/TGJ,_V1N3,_page_131.pdf (15 June 2015).

Trenner, L. 2013. Business coaching for information professionals: why it offers such good value for money in today's economic climate. Business Information Review, 30(1): 27-34. DOI:10.1177/0266382113480020.

Underwood, P. 2009. Supporting the information needs of entrepreneurs in South Africa. Library Review, 58(8): 569-580. DOI:10.1108/00242530910987064.

Wilson, K. and Train, B. 2006. Business information service delivery within a regional context: the role of public libraries. Business Information Review, 23(1): 50-57. DOI:10.1177/0266382106063061.

Wilson, P. 2013. Seven easy steps to supporting small business start ups \& entrepreneurs in Arizona. [Online]. http://jobhelp.azlibrary.gov/pdf/Seven\%20Easy\%20Steps\%20to\%20Supporting\%20Small\%20Business.pdf (2 May 2015).

Wynne, A.T. and Lyne, M.C. 2003. An empirical analysis of factors affecting the growth of small-scale poultry enterprises in KwaZulu-Natal. Development Southern Africa, 20(5): 563-578. DOI:10.1080/0376835032000149225. 